\title{
Intravascular coagulation in acute liver failure in rats and its treatment with antithrombin III
}

\author{
K FUJIWARA, I OGATA, Y OHTA, K HIRATA, Y OKA, S YAMADA, \\ Y SATO, N MASAKI, AND H OKA \\ From the First Department of Internal Medicine, Faculty of Medicine, University of Tokyo, Tokyo, Japan
}

\begin{abstract}
SUMMARY Liver damage was induced in rats by injection of dimethylnitrosamine (DMN) or carbon tetrachloride $\left(\mathrm{CCl}_{4}\right)$. Fibrin clots were observed in the hepatic sinusoids at 12 hours and soluble fibrin monomer complexes were markedly detected at 24 hours only in the rats given DMN. When antithrombin III concentrate was infused at 12 hours there was a dose dependent improvement of the values of serum total bilirubin, SGPT, prothrombin time, peripheral platelet count, and plasma fibrinogen and coagulation factor VIIIC and of the histological degree of liver injury at 24 hours in the DMN group. The $\mathrm{CCl}_{4}$-group showed no such improvement. Intravascular coagulation may complicate the course of certain types of acute liver injury and contribute to its aggravation in rats. Under such circumstances, treatment with antithrombin III concentrate would be beneficial.
\end{abstract}

Both the sinusoidal deposition of fibrin and the increased catabolism of fibrinogen in acute liver failure suggest that intravascular coagulation may contribute to the cell injury in this condition. ${ }^{1-7}$ The efficacy of early treatment of such intravascular coagulation is, however, still unproven. ${ }^{25-7}$ It is not clear whether all types of acute liver failure are accompanied by intravascular coagulation and whether in any specific case it contributes to the aggravation of liver damage.

Fibrinogen is converted into fibrin by thrombin. Thrombin activity can be inhibited by various plasma inhibitors. ${ }^{8}$ Of the well known three protease inhibitors: antithrombin III (AT III), $\alpha_{2}$ macroglobulin and $\alpha_{1}$-antitrypsin, AT III, a serine protease inhibitor produced by the liver, is assumed to be the most important. ${ }^{9}$ Heparin, frequently used in the treatment of intravascular coagulation, accelerates the interaction between AT III and thrombin. ${ }^{11}$ Heparin is effective, therefore, only when sufficient AT III is present. In acute liver failure, where low concentrations of AT III have been reported, substitution with AT III might be

Address for correspondence: Kenji Fujiwara, MD, First Department of Internal Medicine, Faculty of Medicine, University of Tokyo, 7-3-1 Hongo, Bunkyo-ku, Tokyo 113, Japan

Received for publication 7 March 1988. beneficial for the treatment of intravascular coagulation. ${ }^{12-15}$

In this paper, the therapeutic efficacy of AT III in two different models of acute liver damage is evaluated.

\section{Methods}

RATS

INDUCTION OF ACUTE LIVER INJURY

Male Sprague-Dawley rats (Shizuoka Laboratory Animal Center, Shizuoka, Japan), weighing 170$190 \mathrm{~g}$, received $50 \mathrm{mg} / \mathrm{kg}$ body wt dimethylnitrosamine (DMN), ip, as $2.5 \%$ solution in saline or 2.0 $\mathrm{ml} / \mathrm{kg}$ body wt of carbon tetrachloride $\left(\mathrm{CCl}_{4}\right)$ as $20 \%$ solution in olive oil, and were fed a commercial pelleted diet with water ad libitum.

\section{EXPERIMENTS}

Experiment 1

In five rats each given DMN or $\mathrm{CCl}_{4}$, the liver was perfused at 12 hours with saline and then fixative containing $1.5 \%$ glutaraldehyde in $0.067 \mathrm{M}$ cacodylate buffer, $\mathrm{pH} 7 \cdot 4$, and $1 \%$ sucrose $^{16}$ for several minutes through the portal vein under anaesthesia with pentobarbital sodium and was excised for 
electron microscopic examination. Another 10 intoxicated rats were anaesthetised with ether at 24 hours, and blood was collected through the inferior vena cava with a plastic syringe containing $3 \cdot 1 \%$ sodium citrate solution $(1: 10 \mathrm{v} / \mathrm{v})$ for determination of soluble fibrin monomer complexes (FM).

\section{Experiment 2}

Forty rats given DMN and $40 \mathrm{CCl}_{4}$ were divided at 12 hours each into four groups that received infusions of $2 \mathrm{ml} / \mathrm{kg}$ body wt of human AT III (Antithrombin III-Concentrate 500, Behringwerke, Marburg, Germany) at 0 (control rats), 100,200 , or $400 \mathrm{U} / \mathrm{kg}$ body wt. At 24 hours blood was collected similarly with an empty syringe and a syringe containing 1:10 $(\mathrm{v} / \mathrm{v})$ of $3.1 \%$ sodium citrate solution to prepare serum and plasma for determinations of liver function and coagulation parameters, and the liver was excised for histological examination.

\section{DETERMINATIONS OF LIVER FUNCTION AND COAGULATION PARAMETERS}

Peripheral platelets were counted in platelet rich plasma from the citrated blood using a Thrombocounter-C (Counter Electronics, Inc, Hialeah, Florida, USA).

Serum total bilirubin and glutamic pyruvic transaminase (SGPT) were determined in the sera using an autoanalyser and a commercial kit (Iatron Laboratories, Inc, Tokyo, Japan), respectively. Prothrombin time (PT) was measured in the plasma using Simplastin (Division of Warner-Lambert Co, NJ, USA) and a fibrometer (Division of Becton, Dickinson and Company, Cockeysville, MD, USA). Plasma AT III, fibrinogen, coagulation factor VIIIC (VIIIC) and FM were determined using either Test Team Antithrombin III kit (Kabi Diagnostica, Stockholm, Sweden), Fibrinogen Determination Set (International Reagent Corporation, Kobe, Japan), Coagulation Factor VIII Deficient Substrate Plasma (American Dade, American Hospital Supply del Caribe, Inc, Aguada, USA) or FM-test (Boehringer Mannheim, Mannheim, Germany).

\section{HISTOLOGICAL EXAMINATION}

Hepatic histology on light microscope was studied in formalin-fixed and paraffin embedded specimens of the liver stained with haematoxylin and eosin and Masson's trichrome. All slides were evaluated blind by one of the authors.

Electron microscopic examination was carried out as follows: From the excised liver after perfusion, 30 blocks of about 1 cubic mm were made with a blade. They were postfixed in $2 \% \mathrm{OsO}_{4}$ in $0.1 \mathrm{M}$ phosphate buffer, $\mathrm{pH} 7 \cdot 4$, at $4^{\circ} \mathrm{C}$ for two hours, dehydrated in ethanol, and embedded in Epon. Ultrathin sections were observed under a Hitachi H-800 electron microscope at $100 \mathrm{kV}$.

\section{STATISTICAL ANALYSES}

The data for FM levels were analysed by Wilcoxon's two-sample test. The data for liver function and coagulation parameters after AT III infusion were analysed with linear regression analysis; in multiple comparison between the control and three treated groups, corrected $t$ according to Bonferroni's method was used, and the histological changes were analysed with Kendall's correlation.

\section{Results}

COAGULOPATHY IN DMN-AND $\mathrm{CCL}_{4}$ INTOXICATED RATS

Figure 1 shows electron micrographs of DMN intoxicated rat liver. Fibrin clots were observed in the sinusoids where the endothelial cells disappeared. The similar results were obtained in every three to four blocks in all five rats. In $\mathrm{CCl}_{4}$-intoxicated rats, however, there were no fibrin clots in the sinusoids in either block of five rats. They were found only in the necrotic hepatocytes, as shown in Figure 2.

The concentrations of FM were significantly higher in the DMN-group than in the $\mathrm{CCl}_{4}$ group (Table 1).

EFFECT OF AT III INFUSION ON LIVER FUNCTION AND COAGULATION PARAMETERS AND HEPATIC HISTOLOGY IN DMN- AND CCL 4 -INTOXICATED RATS

As shown in Table 2, AT III concentrations were about one fourth of the normal level in both control DMN and $\mathrm{CCl}_{4}$ groups. The increase of serum total bilirubin and SGPT concentrations in the $\mathrm{CCl}_{4}$-group was about twice that in the DMN group. Prothrombin time prolongation did not differ, but fibrinogen was reduced more prominently in the DMN-group. The most remarkable difference between both groups was found in reduction of VIIIC

Table 1 Plasma concentrations of soluble fibrin monomer complex $(F M)$ in rats after dimethylnitrosamine (DMN) or carbon tetrachloride $\left(\mathrm{CCl}_{4}\right)$ intoxication

\begin{tabular}{|c|c|c|c|c|c|}
\hline & $P T^{*}$ & $\begin{array}{l}F M^{+} \\
- \\
\end{array}$ & $\ddagger$ & $\S$ & $\|$ \\
\hline Groups & $(\operatorname{Mean}(S D))$ & Rats (n) & & & \\
\hline DMN & $22 \cdot 1(6 \cdot 5)$ & 0 & 4 & 2 & $4 \pi$ \\
\hline $\mathrm{CCl}_{4}$ & $22 \cdot 1(3 \cdot 9)$ & 0 & 10 & 0 & $0^{* *}$ \\
\hline Normal & $9 \cdot 1(0.3)$ & 10 & 0 & 0 & 0 \\
\hline
\end{tabular}

*PT indicates prothrombin time. $\dagger=$ no turbidity, $\ddagger=$ diffuse turbidity, $\S=$ normal agglutination, and $\|=$ massive agglutination; Ip $<0.01 v \mathrm{CCl}_{4}$ and $\mathrm{p}<0.001 v$ normal; ${ }^{* *} \mathrm{p}<0.001 v$ normal. 

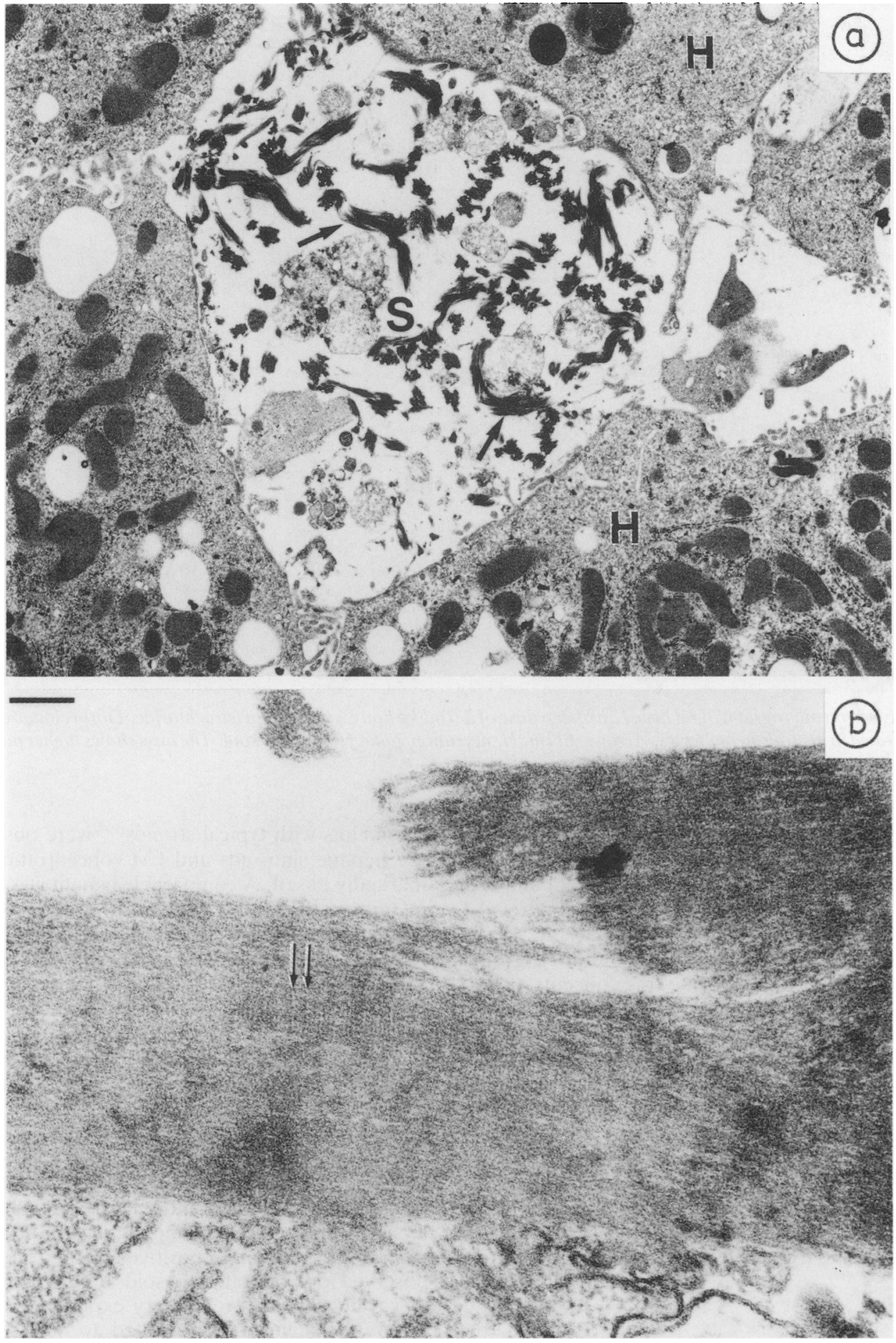

Fig. 1 Electron micrographs of rat liver $12 \mathrm{~h}$ after a dose of $50 \mathrm{mg} / \mathrm{kg}$ body wt of dimethylnitrosamine. (a) Fibrin clots are demonstrated in the sinusoids where endothelial cells disappear. Arrows: fibrins; $H$ : hepatocyte; $S$ : sinusoid. (b) Fibrins show strands with a longitudinal periodicity of $2.3 \mathrm{~nm}$ (arrows). Bar corresponds to $100 \mathrm{~nm}$. 


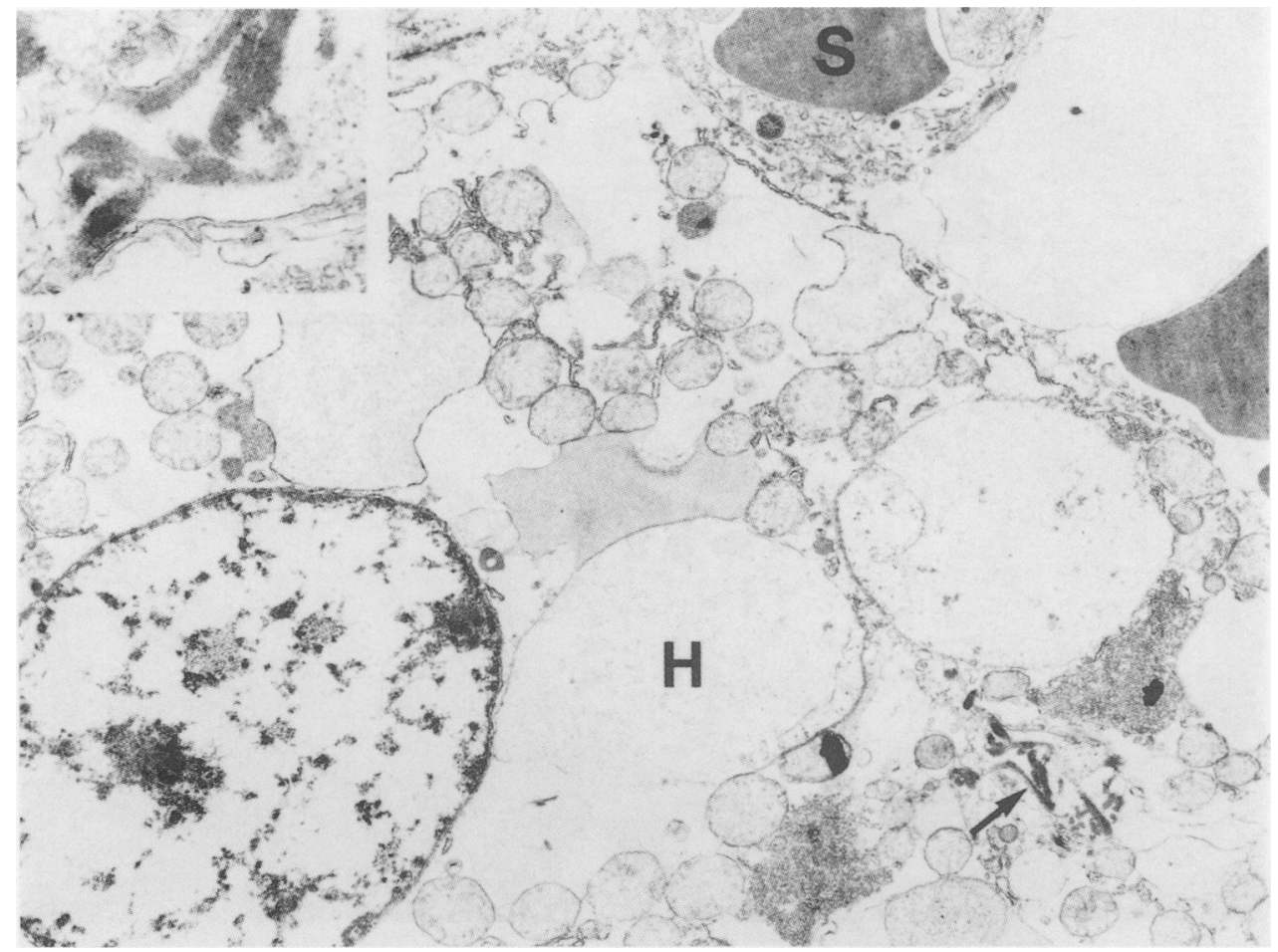

Fig. 2 Electron micrograph of rat liver $12 \mathrm{~h}$ after a dose of $2.0 \mathrm{ml} / \mathrm{kg}$ body wt of carbon tetrachloride. Fibrin clots are demonstrated in necrotic hepatocytes. Arrows: fibrin; H: necrotic hepatocytes; S: sinusoid. The inset shows higher power view of fibrins.

and platelet count. There were negative correlations between concentrations of VIIIC and those of SGPT $(\mathrm{r}=-0.884, \mathrm{p}<0 \cdot 01)$ and serum total bilirubin $(\mathrm{r}=-0.723, \mathrm{p}<0 \cdot 05)$ in the DMN group. After AT III treatment, a dose dependent increase in AT III levels was seen in both $\mathrm{DMN}$ - and $\mathrm{CCl}_{4}$-groups $(p<0 \cdot 001)$. In the DMN group, the concentration of serum total bilirubin $(\mathrm{p}<0 \cdot 01)$, SGPT $(\mathrm{p}<0 \cdot() 1)$, and PT $(p<0 \cdot 01)$ decreased and those of fibrinogen $(p<0 \cdot 01)$, VIIIC $(p<0 \cdot 001)$, and platelet count $(p<0 \cdot 1)$ increased dose dependently with increasing AT III doses. Similar changes were not found in the $\mathrm{CCl}_{4}$ group.

There was a dose dependent improvement on hepatic histology in the extent of injury after treatment in the DMN-group (Table 3). In the $\mathrm{CCl}_{4}$ group, however, no difference was observed between the control and treated groups.

\section{Discussion}

The data presented show that treatment with the AT III concentrate can prevent further expression of liver damage in rats intoxicated with DMN where fibrin clots with typical strands ${ }^{171 \times}$ were observed in the hepatic sinusoids and FM concentrations were markedly raised. A comparable benefit was not seen in those with $\mathrm{CCl}_{4}$ where such changes were not found. Platelet count and VIIIC concentrations were reduced to a greater extent in the DMN model as compared with the $\mathrm{CCl}_{4}$ model even though serum total bilirubin and SGPT concentrations were reversed.

VIIIC concentrations have been reported to increase in fulminant hepatic failure..$^{19}$.11 Although platelets are decreased in acute liver injury, marked reduction is rare without complications. ${ }^{211}=1$ The differences in these parameters between the two models, therefore, suggest that a consumption coagulopathy occurred in the DMN model, and to a lesser extent in the $\mathrm{CCl}_{4}$ model. This would be also supported by strongly positive FM and fibrin clots observed in the hepatic sinusoids in the DMN model. According to our preliminary experiments, such a difference seems to be related to sinusoidal cell destruction of the liver (paper in preparation). Dimethylnitrosamine is thought to cause hepatocellular necrosis by blocking liver protein synthesis, 
Table 2 Concentrations of plasma antithrombin III (AT III), serum total bilirubin, serum glutamic pyruvic transaminase (SGPT), prothrombin time (PT), plasma fibrinogen and coagulation factor VIIIC (VIIIC) and peripheral platelet count in rats treated with $A T$ III after dimethylnitrosamine $(D M N)$ or carbon tetrachloride $\left(\mathrm{CCl}_{4}\right)$ intoxication

\begin{tabular}{|c|c|c|c|c|c|c|c|c|}
\hline \multirow[b]{4}{*}{ Parameters } & \multicolumn{8}{|l|}{ Groups } \\
\hline & \multicolumn{4}{|l|}{$D M N$} & \multicolumn{4}{|l|}{$\mathrm{CCl}_{4}$} \\
\hline & \multicolumn{8}{|c|}{ Doses of ATIII (U/ kg) } \\
\hline & 0 & 100 & 200 & 400 & 0 & 100 & 200 & 400 \\
\hline $\begin{array}{r}\operatorname{AT~III~(\% )~} \\
(105(6))\end{array}$ & $\begin{array}{l}27 \\
(7)\end{array}$ & $\begin{array}{l}37^{*} \\
(9)\end{array}$ & $\begin{array}{l}43 \ddagger \\
(7)\end{array}$ & $\begin{array}{c}68 \S \\
(14)\end{array}$ & $\begin{array}{c}27 \\
(16)\end{array}$ & $\begin{array}{l}48^{*} \\
(16)\end{array}$ & $\begin{array}{c}79 \S \\
(21)\end{array}$ & $\begin{array}{l}130 \S \\
(45)\end{array}$ \\
\hline $\begin{array}{l}\text { Total bilirubin }(\mathrm{mg} / \mathrm{dl}) \\
(<0 \cdot 1)\end{array}$ & $\begin{array}{c}0 \cdot 50 \\
(0 \cdot 27)\end{array}$ & $\begin{array}{c}0 \cdot 29^{*} \\
(0 \cdot 17)\end{array}$ & $\begin{array}{r}0 \cdot 26 \neq \\
(0 \cdot 22)\end{array}$ & $\begin{array}{r}0 \cdot 17 \S \\
(0 \cdot 16)\end{array}$ & $\begin{array}{c}1 \cdot 19 \\
(0 \cdot 45)\end{array}$ & $\begin{array}{c}0.94 \\
(0 \cdot 58)\end{array}$ & $\begin{array}{c}1 \cdot 16 \\
(0 \cdot 51)\end{array}$ & $\begin{array}{c}0.98 \\
(0 \cdot 51)\end{array}$ \\
\hline $\begin{array}{l}\text { SGPT (Karmen unit) } \\
(19(5))\end{array}$ & $\begin{array}{l}1410 \\
(550)\end{array}$ & $\begin{array}{l}1340 \\
(610)\end{array}$ & $\begin{array}{l}860^{*} \\
(360)\end{array}$ & $\begin{array}{l}730 \dagger \\
(510)\end{array}$ & $\begin{array}{c}2500 \\
(1980)\end{array}$ & $\begin{array}{c}1990 \\
(1430)\end{array}$ & $\begin{array}{c}3090 \\
(1940)\end{array}$ & $\begin{array}{l}2540 \\
(1290)\end{array}$ \\
\hline $\begin{array}{l}\mathrm{PT}(\mathrm{s}) \\
\quad(10 \cdot 2(0 \cdot 6))\end{array}$ & $\begin{array}{c}40 \cdot 9 \\
(16 \cdot 1)\end{array}$ & $\begin{array}{l}27 \cdot 4 \dagger \\
(7 \cdot 3)\end{array}$ & $\begin{array}{r}28 \cdot 6^{*} \\
(12 \cdot 6)\end{array}$ & $\begin{array}{l}22 \cdot 2 \ddagger \\
(4 \cdot 6)\end{array}$ & $\begin{array}{c}31 \cdot 3 \\
(17 \cdot 8)\end{array}$ & $\begin{array}{c}29 \cdot 2 \\
(17 \cdot 7)\end{array}$ & $\begin{array}{c}29 \cdot 1 \\
(10 \cdot 9)\end{array}$ & $\begin{array}{c}32 \cdot 1 \\
(18 \cdot 3)\end{array}$ \\
\hline $\begin{array}{l}\text { Fibrinogen }(\mathrm{mg} / \mathrm{dl}) \\
(245(20))\end{array}$ & $\begin{array}{l}64 \cdot 6 \\
(32 \cdot 6)\end{array}$ & $\begin{array}{l}71 \cdot 5 \\
(33 \cdot 3)\end{array}$ & $\begin{array}{c}89 \cdot 4 \\
(52 \cdot 1)\end{array}$ & $\begin{array}{l}124 \cdot 7 \dagger \\
(51 \cdot 0)\end{array}$ & $\begin{array}{l}132 \cdot 3 \\
(82 \cdot 6)\end{array}$ & $\begin{array}{c}153 \cdot 0 \\
(130 \cdot 0)\end{array}$ & $\begin{array}{l}104 \cdot 0 \\
(47 \cdot 7)\end{array}$ & $\begin{array}{l}134 \cdot 2 \\
(93 \cdot 2)\end{array}$ \\
\hline $\begin{array}{l}\operatorname{VIIIC}\left(\mathrm{u} / \mathrm{ml} \times 10^{2}\right) \\
(290(90))\end{array}$ & $\begin{array}{c}2 \cdot 0 \\
(0 \cdot 4)\end{array}$ & $\begin{array}{c}2 \cdot 2 \\
(0 \cdot 3)\end{array}$ & $\begin{array}{c}2 \cdot 2 \\
(0 \cdot 4)\end{array}$ & $\begin{array}{r}2 \cdot 8 \ddagger \\
(0 \cdot 8)\end{array}$ & $\begin{array}{l}101 \cdot 1 \\
(77 \cdot 6)\end{array}$ & $\begin{array}{c}45 \cdot 3 \\
(48 \cdot 8)\end{array}$ & $\begin{array}{l}51 \cdot 8 \\
(58 \cdot 3)\end{array}$ & $\begin{array}{c}131 \cdot 1 \\
(169 \cdot 5)\end{array}$ \\
\hline $\begin{array}{l}\text { Platelet }\left(\times 10^{4} / \mathrm{mm}^{3}\right) \\
(100 \cdot 4(7 \cdot 3))\end{array}$ & $\begin{array}{l}18 \cdot 3 \\
(3 \cdot 9)\end{array}$ & $\begin{array}{l}19 \cdot 2 \\
(7 \cdot 0)\end{array}$ & $\begin{array}{l}17 \cdot 5 \\
(4 \cdot 0)\end{array}$ & $\begin{array}{l}23 \cdot 3^{*} \\
(8 \cdot 2)\end{array}$ & $\begin{array}{c}81 \cdot 6 \\
(12 \cdot 8)\end{array}$ & $\begin{array}{c}78.8 \\
(15.5)\end{array}$ & $\begin{array}{c}69 \cdot 8 \\
(23 \cdot 3)\end{array}$ & $\begin{array}{c}67 \cdot 8 \\
(14 \cdot 7)\end{array}$ \\
\hline
\end{tabular}

Results are mean (SD) of 10 rats except for nine rats in the $\mathrm{CCl}_{4}$-group treated by $100 \mathrm{U} / \mathrm{kg}$ of AT III where one rat was killed by anaesthesia at the time of AT III infusion. Results in parentheses are the mean (SD) of five normal rats. ${ }^{*} \mathrm{p}<0 \cdot 1 ; \nmid \mathrm{p}<0 \cdot 05 ; \ddagger \mathrm{p}<0 \cdot 01 ; \S \mathrm{p}<0 \cdot 001 v 0$ dose of ATIII.

while $\mathrm{CCl}_{4}$ by immediate injury to the plasma membrane. $^{22}$ The mechanism of liver injury must be further investigated.

Because treatment with AT III did not affect the course of the $\mathrm{CCl}_{4}$ induced liver injury, the treatment is unlikely to have direct effects on hepatocellular damage. In this model where fibrin clots were present only in the necrotic hepatocytes, coagulation parameters were not changed by the treatment. Infused AT III might not have perfused effectively in these areas, though the reason is obscure. In the

Table 3 Histological changes of hepatocellular necrosis and degeneration in rats treated with antithrombin III (AT III) after dimethylnitrosamine intoxication

\begin{tabular}{lllll}
\hline & \multicolumn{4}{l}{$\begin{array}{l}\text { Extent of necrosis and degeneration* } \\
\text { (Grades) }\end{array}$} \\
\cline { 2 - 5 } $\begin{array}{l}\text { Doses of } A T I I I \\
\text { (U/kg) }\end{array}$ & 1 & 2 & 3 & 4 \\
\hline 0 & 0 & 2 & 5 & 3 \\
100 & 1 & 1 & 7 & 1 \\
200 & 0 & 4 & 5 & 1 \\
400 & 2 & 4 & 4 & 0 \\
& $\mathrm{r}_{\mathrm{k}}=-0 \cdot 350, \mathrm{p}<0 \cdot 05$ & & \\
\hline
\end{tabular}

Figures indicate number of rats. ${ }^{*}$ The extent was classified according to the extent or numbers of the findings of karyorrhexis $(\mathrm{K})$, cell debris (CD), and spotty necrosis with blood filled spaces (SN) in addition to acidphilic degeneration in the centrizonal areas as follows: Grade 1: $\mathrm{K}-, \mathrm{CD}-, \mathrm{SN}-;$ grade $2: \mathrm{K}-\mathrm{CD} \pm, \mathrm{SN} \pm$; grade $3: \mathrm{K}+, \mathrm{CD}+, \mathrm{SN}+$; grade $4: \mathrm{K}++, \mathrm{CD}++, \mathrm{SN}++$.
DMN model, reduced fibrinogen concentrations were markedly attenuated by the treatment. The benefit of AT III for liver damage observed in this model would be the result of its effect on formation of fibrin clots in the sinusoids.

Rake et $a l^{4}$ showed in a $\mathrm{CCl}_{4}$ rat model that an excessive deposition of ${ }^{125}$ I-fibrinogen in the liver could be delayed by heparin treatment. The coagulopathy and the increased catabolism of fibrinogen observed in this model was similar to the phenomena found in patients with acute hepatic necrosis. The authors did not describe, however, the relation of these changes to the degree of liver damage. MullerBerghaus $e t a^{5}$ induced hepatitis and disseminated intravascular coagulation in rabbits by the administration of galactosamine and fibrinolysis inhibitor. The authors could prevent the formation of microclots by treatment with heparin. This treatment did not show any influence on total bilirubin or SGPT. The conclusions drawn from these observations remain equivocal, however, because it is known that heparin does not inhibit thrombin activity in the absence of AT III." The experiments presented in this paper provide evidence that intravascular coagulation occurs and varies with the type of injury in rats. Intravascular coagulation may be a contributing factor to the aggravation of the injury. Therapy with AT III concentrate would be of benefit for such types of acute hepatic failure.

Our experimental models may differ in the mech- 
anism of development of injury from acute liver failure commonly encountered in humans. However, from the fact that acute liver failure takes different courses, ${ }^{2324}$ and hence the pathological state of disease might vary also in man, the present results would provide useful hints for considering such situation.

This work was supported in part by Grant-in-Aid for Scientific Research from the Ministry of Education Science and Culture of Japan and in part by Research Grant from the Intractable Diseases Division, Public Health Bureau, Ministry of Health and Welfare, Japan. This work was presented in part at the 6th International symposium on Gastroenterological Emergencies, Munchen, Germany, 2 May, 1986.

\section{References}

1 Rake MO, Flute PT, Pannell G, Williams R. Intravascular coagulation in acute hepatic necrosis. Lancet 1970; i: 533-7.

2 Rake MO, Flute PT, Shilkin KB, Lewis ML, Winch J, Williams R. Early and intensive therapy of intravascular coagulation in acute liver failure. Lancet 1971; ii: 1215-8.

3 Clark R, Borirakchanyavat V, Gazzard GB, et al. Disordered hemotasis in liver damage from paracetamol overdose. Gastroenterology 1973; 65: 788-95.

4 Rake MO, Flute PT, Pannell G, Shilkin KB, Williams R. Experimental hepatic necrosis: Studies on coagulation abnormalities, plasma clearance, and organ distribution of ${ }^{125}$ I-labelled fibrinogen. Gut 1973; 14: 574-80.

5 Muller-Berghaus G, Reuter C, Gleyl U. Experimental galactosamine-induced hepatitis. Effect of anticoagulant and anti-fibrinolytic agents on microclot formation. Am J Pathol 1976; 8: 393-406.

6 Hillenbrand P, Parbhoo SP, Jedrychowski A, Sherlock S. Significance of intravascular coagulation and fibrinolysis in acute hepatic failure. Gut 1974; 15: 83-8.

7 Gazzard BG, Clark R, Borirakchanyavat V, Williams $R$. A controlled trial of heparin therapy in the coagulation defect of paracetamol-induced hepatic necrosis. Gut 1974; 15: 89-93.

8 Lammle B, Griffin JH. Formation of the fibrin clot: The balance of procoagulation and inhibitory factors. In:
Ruggeri ZM, ed. Clinics in haematology. Philadelphia: WB Saunders, 1985: 281-342.

9 Downing MR, Bloom JW, Mann KG. Comparison of the inhibition of thrombin by three plasma protease inhibitors. Biochemistry 1978; 17: 2649-53.

10 Rosenberg RD, Damus PS. The purification and mechanism of action of human antithrombin-heparin cofactor. J Biol Chem 1973; 248: 6490-505.

11 Damus PS, Hicks M, Rosenberg RD. Anticoagulant action of heparin. Nature 1973; 246: 355-7.

12 Verstraete M, Vermylen J, Collen D. Intravascular coagulation in liver disease. Annu Rev Med 1974; 25: 447-52.

13 Sakata Y, Yoshida N, Matsuda M, Aoki N. Treatment of DIC with antithrombin III concentrates. Bibl Haematologica 1983; 49: 307-16.

14 Laursen B, Mortensen JZ, Frost L, Hansen KB. Disseminated intravascular coagulation in hepatic failure treated with antithrombin III. Thromb Res 1981; 22: 701-4.

15 Vogel GE. Early treatment with AT III in acute liver failure. Behring Inst Mitt 1983; 73: 79-93.

16 Wisse E. An electron microscopic study of the fenestrated endothelial lining of rat liver sinusoids. J Ultrastruct Res 1970; 31: 125-50.

17 Cecil EH, Slayter HS. The fibronogen molecule: Its size, shape, and mode of polymerization. J Biophys Biochem Cytol 1959; 5: 11-6.

18 Kay D, Cuddigant BJ. The fine structure of fibrin. $\mathrm{Br} \mathrm{J}$ Haematol 1967; 13: 341-7.

19 Meili EO, Straub PW. Elevation of factor VIII in acute fatal liver necrosis. Thromb Diathes Haem 1970; 24: 161-74.

20 Langley PG, Hughes RD, Williams R. Increased factor VIII complex in fulminant hepatic failure. Thromb Haemost 1985; 54: 693-6.

21 Roberts HR, Cederbaum AI. The liver and blood coagulation: physiology and pathology. Gastroenterology 1972; 63: 297-320.

22 Zimmerman HJ. Experimental hepatotoxicity. In: Eichler $\mathrm{O}$, ed. Handbook of experimental pharmacology, Vol XVI Experimental production of diseases. Part 5: Liver. Berlin: Springer-Verlag, 1976: 1-120.

23 Gimson AES, Williams R. Acute hepatic failure: aetiological factors, pathogenic mechanisms and treatment. In: Thomas HC, MacSween RNM, ed. Recent advances in hepatology 1. London: Churchill Livingstone, 1983: 57-69.

24 Takahashi Y. Acute hepatic failure - In special relation to treatment. Jpn J Med 1983; 22: 140-5. 